Menoufia J. Animal, Poultry \& Fish Prod., Vol. 1 December (2017): 43 - 44

\begin{tabular}{|c|c|}
\hline Department & Animal Production \\
\hline Field of study & Animal Production \\
\hline Scientific Degree & Ph. D. \\
\hline Date of Conferment & Jan. 18,2017 \\
\hline Title of Thesis & $\begin{array}{l}\text { DEVELOP SOME INTEGRATED PARAMETERS TO ASSESS } \\
\text { ANIMAL ON FARMS WELFARE USING MULTIPLE BEHAVIORAL } \\
\text { CRITERIA. }\end{array}$ \\
\hline Name of Applicant : & Elsayed Eldahshan Elsayed Soliman Eldahshan \\
\hline $\begin{array}{l}\text { Supervision Committee } \\
\text { - Dr. S. H. El-kasch } \\
\text { - Dr. S. S. Omar } \\
\text { - Dr. Elham M. Ghonai }\end{array}$ & $\begin{array}{l}\text { Prof. of Animal Husbandry, Fac. of Agric., Menoufia Univ. } \\
\text { Prof. of Animal Husbandry, Fac. of Agric., Menoufia Univ. } \\
\text { Assistant Prof. of Animal breeding, Fac. of Agric., Menoufia Univ. }\end{array}$ \\
\hline
\end{tabular}

\begin{abstract}
The present study included tow experiments. The first One was at the animal behaviour research unit, faculty of agriculture, Minufiya University, to develop some integrated parameters to assess animal's on-farm welfare using multiple criteria. The Second one was performed to evaluate the current level of welfare of Egyptian buffaloes under different production systems, using the specific method described in the Welfare Quality ${ }^{\circledR}$ Assessment Protocol for Cattle. Assessment was performed on 163 animals in 15 Egyptian dairy buffalo farms which represent 3 production systems (Traditional farms (I), Faculty farm (II) and Commercial farm (III)). Results of the present study revealed that The suggested behaviour models for Egyptian Buffaloes for lying, eating and ruminating were 75.34, 30.90 and 27.04 min./time, Representing 47.04, 28.31 and \% of the day and frequent 8.99, 13.19 and 16.48 times per day. Kicking, Stepping and Tail movement behaviour, during milking, model should be (0.14-0.09 kick/min., 0.68-1.35 Step/min. and 4.35 -5.35 time / min. resp. at total milking period. Milk production was $(3.09 \pm 0.13 \mathrm{~kg})$ per milking with an average of $0.43 \pm 0.02 \mathrm{~kg} / \mathrm{min}$ milk flow rate. Bacterial count in raw milk was $6.0 \times 10^{5} \mathrm{cfu} / \mathrm{ml}$. Egyptian buffaloes have $4.45 \pm 0.65$ [ng/ml] Serum cortisol. Very lean buffaloes represent $65 \%$ and $47 \%$ of animals in Farm I and farm II respectively. However there is no any very lean animal in farm III. Studied animals in farm 1 lied down within $11 \mathrm{sec}$. on the other hand time needed to lie down were 9 and $6 \mathrm{sec}$. in farm 2 and 3 respectively. All investigated disease had had lower values. This may be due to high immunity level of Egyptian buffaloes against cows.
\end{abstract}

Key words: Animal behavior, integrated parameters, animal's on-farm welfare, multiple criteria. 


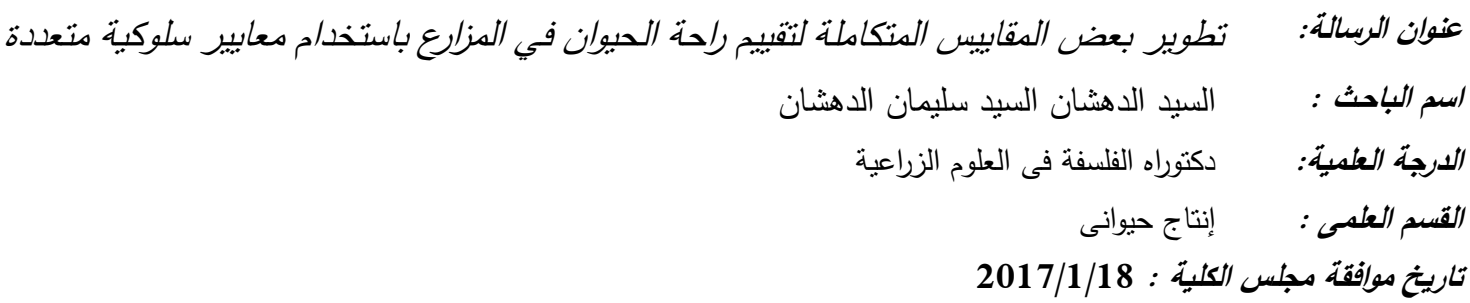

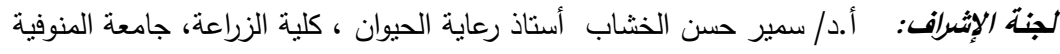

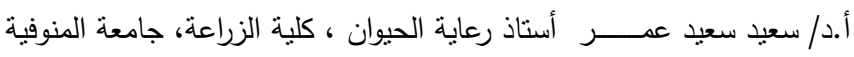

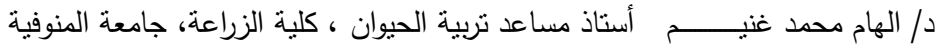

\section{الملخص العربى}

أجريت هذه الدراسة في تجربتين. نم اجراء التجربة الأولى في مزرعة الانتاج الحيواني البحثية بكلية الزراعة جامعة المنوفية- مصر • وقد اجريت التجربة بغرض تطوير بعض المقاييس المتكامله لتقيم راحة الحيوان داخل المزرعه باستخدام معايير متعدده. وقد اجريت التجربه الثانيه بغرض تقيم مسنوى رفاهية الجاموس المصري تحت نظم انتاجيه مختلفه باستخدام

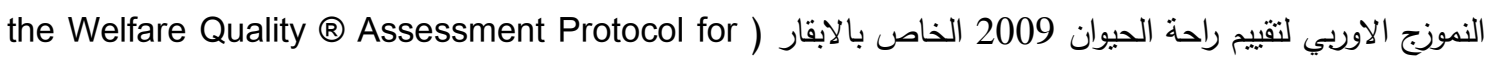
(Cattle, تقليديه ومزرعه بحثيه ومزرعه تجاريه) وقد اثنارت نتائج التجربة الأولى الى ان النموذج المقترح لسلوك الرقاد والاكل والاجترار

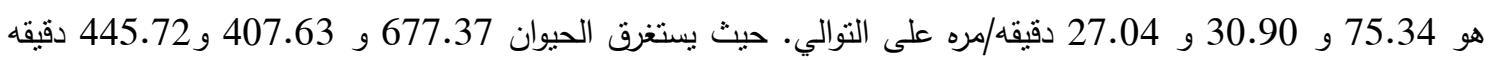

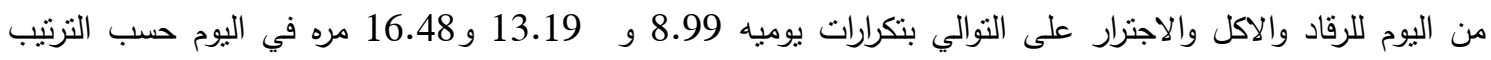

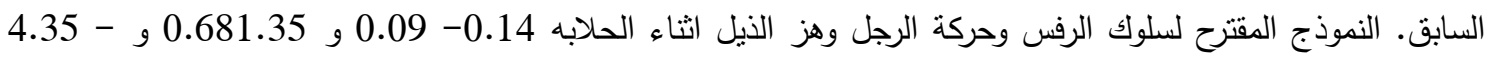
5.35 مره / دقيقه بالترتيب خلال فترة الحلابه الكليه. انتج الجاموس الحلاب 3.09 كجم لبن كمتوسط في الحلبه الواحده

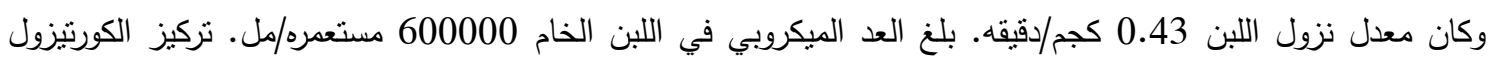

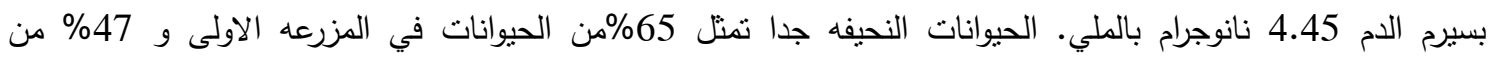
الحيوانات في الثانيه ولكن لم يوجد اي حيوان نحيف في المزرعه الثالثه. استغرقت الحيوانات في المزرعه الاولى 11 ثانيه

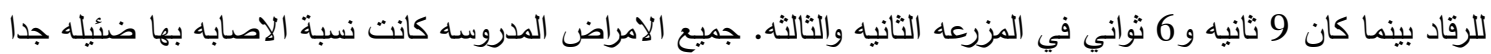
لارتفاع مناعة الجاموس المصري. 